\title{
Stakeholders Perception on Mandated CSR Laws in Indonesia
}

\author{
Rabin Ibnu Zainal * \\ Universitas Bina Darma \\ Palembang, Indonesia
}

\begin{abstract}
Indonesia has been known as one of the first country having CSR mandatory regulatory approach. This paper tries to examine the perception of the companies and the local community members on the implementation of this CSR law. The paper firstly identifies what has been mandated by CSR law in Indonesia, and some circumstances that may affect the implementation of CSR law. Then, it continues to examine the companies and local community perceptions. The research finds that the implementation of CSR law is challenged by some circumstances in the local context, as a result of the decentralization that has distributed the power and authority to the local stakeholders. The dark side of decentralization such as the local corruption and bribery has impacted the way CSR implemented in the field. Therefore, the implementation of the law probably are not in line with its goal anymore, which is to improve the local people life.
\end{abstract}

Keywords-CSR, Stakeholder, Perception, Indonesia.

\section{INTRODUCTION}

According to Article 33 (3) (Government of Republic of Indonesia, 1945) stated that "Earth, water, and natural resources contained within the earth shall be under control of the state and shall be used for the maximum welfare of the people". Article 33 of UUD 1945 (the basic constitution) has a powerful notion that Indonesia national economy is controlled by the state government for the peoples' welfare. However, how this article achieved its goal is still in big question. In fact, the study conducted in the local community living in mining areas, found that the number of poverty is still high in the area where natural resources are abundance [1]. These situations encouraged the government to pass regulations to mandate CSR to the companies related to natural resources. The law acknowledges as a world-first regulation of CSR in 2007 [2]. The regulation has aimed to force businesses to be actively involved and contribute to addressing the local social problems such as poverty [3].

With this background, the main objective of this study is to understand the company and local community perception on the implementation of CSR law in the field. Thus, some specific research questions have been set to achieve the main objective of this paper: (1) What is mandated by CSR law?; (2) What circumstances that influence the CSR law implementation?; and (3) How do the company and local community perceive on the implementation of CSR law?

\section{LITERATURE REVIEW}

\section{A. CSR and development}

The development efforts to improve the living conditions of developing countries discussed intensively in some development theories. It started from the polarized view of economic growth, which often relates to the exploitation of countries' resources to generate more national income [4], [5]. This implies the idea of business responsibility where the business is placed as the dominant engine of economic growth and creates economic value and managerial resources. With this role, the companies then have the obligation to contribute the economic growth and even become an active partner in managing the developing countries resources [6]. The increasing attention on development issues recently went beyond the economic growth view. Many aspects incorporate the notion of development such as Human Development Index (HDI) that includes the life expectancy at birth, composite school of enrolment, and adult literacy and GDP [7]. Hence many basic needs also being acknowledged for development in developing countries such as water and provision of food, housing and other forms of material welfare, health service and education, human rights and gender equality, democracy and freedom, a fair distribution of economic growth, and the sustainable use of natural resources [5]. The broad development indicators have been able to shift the ideas of development for not only limited to focus on economic, but also to the social development perspective [8]. [9] asserted that the differences in the environment and priorities of people in developing countries may result in the company being expected to fulfill the social obligation in developing countries. Moreover, government and civil society now see CSR as a bridge connecting the arenas of business development and increasingly discuss CSR programs in terms of their contribution to development. Thus, it should be noted that a critical agenda of CSR programs in developing countries are regarding their contribution to development-related issues such as reducing poverty and building human capital [4].

Implementing this new social development role of business is not without challenges. CSR concepts are mostly developed in western countries where they have comprehensive environmental regulations, labor unions, and a wealth of consumer demands. The presence of social institutions in western developed countries generates 'invisible' pressures to the companies to adopt voluntary CSR practices [10], [11]. Conversely, in the developing countries where there tends to 
be weak enforcement of legislations and rampant corruption, the pressures to companies may be unclear. The companies typically may find themselves in a position to self-regulate considered the lack of monitoring and consultation from the government (Jamali \& Mirshak, 2007). Whilst in another case the situation may also lead the government to force the businesses to take a role in social provisions through law and regulation which put the companies in the position as 'sort of de facto government' or 'alternative to government' [11].

$B$. The type of CSR regulation

The government in developing countries like Indonesia is now more aware of the importance of CSR as a potential contributor for development in their countries. Thus, government intervention in recent years has been recognized as one of CSR drivers [12]. A reciprocal relationship should become a basis for government to intervene CSR. The government depends on the markets for the efficient provision of goods and services that enhance social well-being and in return, markets depend on government rules to function efficiently and fairly. The regulations as a tool of government intervention should achieve an optimum balance between public-private of state intervention and market freedom. This basic thinking on government-business relationship posits two school of thinking; 'the civic governance' whereby the state is required to intervene to protect public goods, and the opposite thinking on 'consumer sovereignty' model of laissez-faire market dynamics and minimum government intervention [13], [10], [14]. The debates of these two school of thinking derive a question on the form of CSR regulations, whether the companies CSR performance is best achieved by "hard law" through legislated regulatory intervention or by "soft law" by delegated voluntary approaches that leverage the power of the market to move companies to be socially responsible?

Table 1. Hard law versus soft law regulatory approaches

\begin{tabular}{|c|c|c|}
\hline Type of intervention & $\begin{array}{c}\text { Hard law } \\
\text { (prescriptive) }\end{array}$ & Soft law (voluntary) \\
\hline Setting standards & $\begin{array}{l}\text { Regulatory } \\
\text { prescription- } \\
\text { traditional command } \\
\text { and control regulation } \\
\text { in which legally } \\
\text { binding standards are } \\
\text { prescribed }\end{array}$ & $\begin{array}{l}\text { Information- influence } \\
\text { constituents through } \\
\text { the transfer of } \\
\text { knowledge and the } \\
\text { communication of } \\
\text { reasoned argument } \\
\text { and persuasion }\end{array}$ \\
\hline Enforcing standards & $\begin{array}{l}\text { Economic regulatory } \\
\text { instruments- examples } \\
\text { include pollution fees, } \\
\text { emission taxes, and } \\
\text { tradable permits to } \\
\text { encourage firms to } \\
\text { internalize } \\
\text { environmental costs }\end{array}$ & $\begin{array}{l}\text { Voluntary approaches- } \\
\text { examples include } \\
\text { industry self- } \\
\text { regulation, codes, } \\
\text { voluntary challenges, } \\
\text { eco-labels, charters, } \\
\text { co-regulation, } \\
\text { covenants, and } \\
\text { negotiated } \\
\text { environmental } \\
\text { agreements } \\
\end{array}$ \\
\hline
\end{tabular}

Source: [15]

Table 1 shows the difference between hard law and soft law approach in regulating CSR. The type of government intervention can be in two forms; by setting standards and by enforcing standards. However, these two forms of intervention have different approaches in soft law and hard law. In hard law, the prescriptive approach where the government setting command and control to businesses to legally bind the businesses are prescribed. Some enforcing efforts are also introduced by the government through taxing, fees, and permits that are authorized by the government. In contrast, the soft law approach tends to focus on the transfer of knowledge and communication of government and businesses, so businesses voluntarily can apply some standards in their CSR. Government intervention in soft law approach also prefers to encourage self-regulation of businesses through giving a reward such as Eco labeling.

Many studies have investigated the advantages and disadvantages of soft law versus hard law approaches. The hard law approach in regulation is generally criticized for being slow and expensive to develop, operate, and amend; for fostering adversarial relations; for dampening innovation and beyond-compliance behavior; and for producing unintended outcomes. Whilst the soft law voluntary approaches such as self-regulation of businesses are also criticized for being difficult to apply, for being less rigorous in their performance requirements, and for their uncertain public accountability [15].

The industry generally prefers to use a voluntary approach rather than regulatory approaches, as this avoids the imposition of inefficient regulation while at the same time providing a flexible framework for innovation. Further, industry argues that self-regulation generates business process improvements and positive changes in the corporate culture that are often hard to quantify. Policy scholars also argue that voluntary approaches can enhance efficiency and effectiveness by positioning the development and implementation of agreements in the hands of those closest to and most knowledgeable about the issues [16]. Conversely, [17] disagree with the proposition that government intervention can raise businesses cost as they argue that properly designed regulations can trigger innovations that can offset the costs of reducing the negative effect of operations, resulting in efficiencies and making companies more competitive in the global market.

\section{METHOD}

The research employs qualitative study to explore the participants' expectations, perceptions, and perceived. The interpretive approach is chosen to adopt 'practical orientation' which focuses on 'how people manage their practical affairs in everyday life or how they get things done' [18]. However, the research would also admit the influenced of contextual background in the way research conducted. Contextual sensitivity related to the cultural sensitivity of participants in Indonesia allows researcher to employ some strategies to be involved with the research participants.

\section{A. Research context and participants}

The study is conducted in Musi Banyuasin district in South Sumatera Province, Indonesia. The regency is well-known for its natural resources such as oil, gas, and coal [20]. The local government has initiated to establish a CSR forum to improve 
consultation between stakeholders in CSR projects. The forum is membered by all companies operated in Musi Banyuasin District and led by several district government officials, but absent from the local community participation. Despite the establishment of this forum, the relationship of companies with their local stakeholders has been on alert with several demonstrations and protests from the local communities regarding companies' activities.

This study had selected participants from the company and the local community. For the company group, this study selected three companies related to natural resources and membered of CSR forum. The managers and staff of these companies then had been contacted to participate in this study. On the other hand, the local community is selected from the local people living near the selected company.

Table 2 shows the research participants from the companies and local community groups.

Table 2. Research participants

\begin{tabular}{|l|l|l|}
\hline No. & Participant Group of & $\begin{array}{l}\text { Number } \\
\text { Participant }\end{array}$ \\
\hline 1 & $\begin{array}{l}\text { Managers and Staff who handle } \\
\text { the company CSR }\end{array}$ & 13 \\
\hline 2 & $\begin{array}{l}\text { Local Community Members } \\
\text { (Head of Village, Religious } \\
\text { Leaders Young Leaders, } \\
\text { women leaders) }\end{array}$ & 37 \\
\hline \multicolumn{2}{|l|}{ Total Participants } & 40 \\
\hline
\end{tabular}

\section{B. Data collection method}

This research deals with qualitative data. The exploration of participants' meanings in natural settings can use interview methods [20]. The focus group discussion was also conducted, particularly to the local community groups. In addition, for better understanding of participants' perspective, the researcher also complemented the interviews and discussion with some observations and existing secondary data [21]. Through these combined methods, the researcher is able to identify any contradictions between what people do and what people say [20]. Interview and discussion is in semistructured following the exploratory research type which aims to 'understand phenomena that are poorly understood' [22]. The way CSR interprets would be assessed through participants meaning and interpretation as [23] also asserted that individuals are best placed to describe situations and feelings in their own words. The way people interpret and make sense of their experiences and the world in which they live is the approach of qualitative exploratory research to explore the behavior, perspectives and experiences of the people they study [24].

C. Data analysis method

Multiple types of data, including documents and field notes from interviews and observation will be analyzed. This collected data requires the researcher to choose the analytic strategy and technique to "treat evidence fairly, produce compelling analytic conclusions, and rule out alternative interpretations" [25]. The strategy in this research is used 'case descriptive' for organizing the case study due to the complexities of cases. This strategy allowed the researcher to describe and relate the context of each case. In line with this strategy, the explanation-building technique is employed to explain a phenomenon by answering 'how' and 'why' questions to the findings [25] Interpretive approach is one way to do this. [21] suggested that an interpretive approach can deal with multiple perceptions and meanings where perceptions and meanings come from thinking and behavior in the 'natural settings' context. This can be obtained from an effective relationship between the researcher and participants, so people identify what they see as significant and tell their stories in the ways they want [21]. In this manner, the researcher established a good relationship with the participants to be a "friendly outsider" [26] to access the participants' 'physical access' and 'mental access' [27]. So, some key themes noted by the researcher during interviews and discussions can be clarified during interviews and discussions.

\section{RESUlts AND DisCUSSION}

The findings and analysis of this study are followed the research questions to achieve the main objective of the research. The findings and analysis, therefore, consist of some themes; what is mandated in CSR regulation, some circumstances that influence the law implementation, and the perceptions of companies and local community members toward the CSR implementation.

\section{A. What is mandated in CSR Law?}

The article 74 of Law No. 40/ 2007 on Limited Liability Company states the following (Government of Republic of Indonesia, 2007):

(1) Limited liability companies that carry out business activities in natural resource sectors or that are connected with natural resources are obliged to implement Corporate Social and Environmental Responsibility.

(2) Corporate Social and Environmental Responsibility, as referred to in paragraph (1) represent a responsibility of a limited liability company that is budgeted for and calculated as an expense of that company, the implementation of which is to be carried out paying attention to appropriateness and propriety.

(3) Limited liability companies that do not implement their obligation as referred to in paragraph (1) will incur sanctions in accordance with the provisions of legislative regulation.

(4) Further provisions concerning Corporate Social and Environmental Responsibility will be regulated in a Government Regulation.

Government Regulation No. 47 of 2012 on Corporate Social and Environmental Responsibility has been issued on 4 April 2012 to implement this Article 74 of Law No. 40 of 2007 on Limited Liability Companies. This is a long-awaited piece of implementing legislation clarifying the nature of the required corporate social responsibility (CSR) activities, which have been a vague requirement for nearly five years [28]. Article 2 in the regulation states that all limited liability companies have 
Communication Forum of Districts Producing Oil and Gas) often complain of the calculation this fiscal balance of oil and gas revenue-shared. The lack of transparency in calculating the annual fiscal balance from the central government is often protested by the local district governments [31].

Apart from their requests on fair fiscal balance, the local governments recently are more aware of CSR as well. In this manner, CSR may provide an alternative budget for the local government. Hence through set of CSR law/ regulation, the central government force the company to 'support the local government' in providing social needs in the area or as [4] stated as an 'alternative to government'.

conclude that the main objective of the CSR regulation in Indonesia is: the redistribution of resources and wealth from private companies, both foreign and domestic, to local communities in order to ensure development and prosperity for the people of Indonesia. Despite regulating how the company builds relationships and implement CSR with the local community, the regulation tends to only regulate and ensure the company to allocate their budget for CSR. It means that CSR law actually is not regulated the way companies carry out their business more responsible, but it is about how the company transfers and redistributes its wealth to the local community. This type of CSR such as community development, donation, philanthropy, supporting small and medium-sized enterprises (SMEs), and environmental rehabilitation may not in line with the CSR concepts in the literature where presumably CSR can increase shareholders wealth by making companies more efficient and competitive [29]. Conversely, this type of CSR may result in the decrease of shareholders' wealth by distributing the shareholders' wealth through CSR projects to the community.

B. The Circumstances in Implementing CSR Law

After identifying the idea of the CSR laws, we also need to understand the context where the law is implemented. The research identifies some circumstances that challenge the implementation of this law, such as; 1) the distributing power to local government, 2) The powerless of Marginalized group, and 3) the corruption practices.

\section{1) The Distribution of Power and Authority}

Decentralization has distributed some authorization powers to local government officials. The demand of locals to require more benefit from companies has increased during decentralization in return for access to natural resources and cheap labor. In terms of natural resource control, the contesting power of central and local government is typically reflected in the intergovernmental fiscal regulations. Some of the important mining resources, such as oil and gas, are remain controlled by central government, whilst the local governments at the provincial and district level gain revenueshared from the central government in fixed proportions [30]. This inter-governmental fiscal relationship has generated a sense of the regional disparity between the center and the regions. The natural resources-rich districts and provinces, in particular, felt that this fiscal balance policy has been unfair. Some local district governments membered of FKDPM (Forum Komunikasi Daerah Penghasil Migas -

\section{2) The Powerless of Marginalized group}

Decentralization has allowed the local community participations in the government policies which was neglected head) and walikota (mayor), are now more accountable to their constituents since they are directly elected, not appointed by the central government in Jakarta. Further, the head of the villages is technically accountable to the villagers as now they are elected by the community and controlled by Badan Perwakilan Desa (Village Representative Board). Musbangdes (village development forum) is conducted every year to allow the aspirations of local communities toward the development projects. The ability to control their own land and resources has enabled them to gain benefit from businesses. They are now able to demand compensation from businesses, indeed many local stakeholders now require numerous promises from companies, such as jobs, money, and agricultural inputs before they grant permission to use their land [44],[33].

However, Duncan (2011) found that decentralization may only benefit to certain group in the communities due to political power that they have. It is agreed that decentralization is able to increase localism in which the local communities' ownership over resources is granted. But decentralization may only recognize people that have power and influence, while the minority groups such as those who do not have access to the ownerships of local resources such as land, education, etc will remain neglected in the system [32], [23], [34].

\section{3) The Corruption Practices}

According to the World Bank \& IFC Enterprise Surveys (2009), nearly $15 \%$ of the surveyed companies expect to pay bribes to public officials to 'get things done' and 14\% state that corruption is a major problem for doing business in Indonesia. Bribery typically occurs during licensing procedures. According to the same source, foreign companies report that unwarranted fees or facilitation payments are required in order to obtain permits and licenses, to speed up processes or to win government contracts and concessions. In this circumstance, CSR may be used as the instrument of the company to approach specific stakeholders, so these stakeholders may assist the company to some benefit such as; getting licenses to operate, avoiding people complains, and in the previous regime. Regional leaders, bupati (the district 
of local communities in CSR program is derived from the lack of consultation with the community members. They added that the company only intends to consult with certain stakeholders. The company objectives to use CSR to calm down the local protests may affect how the company identifying and selecting the stakeholders. Some certain stakeholders that have power and influence in the community may be prioritized to secure the company interests. The study noted some CSR projects for this type of stakeholders such as; 1) giving accommodation during their out-of-town duties, 2) financing selected cooperative (koperasi) administered by certain stakeholders, and 3) conducting CSR projects requested by certain stakeholders for their own purposes and interests. In the literature, this implementation is part of the instrumental approach of CSR. The instrumental approach refers CSR to the direct relationship between CSR and firm performance, and often is related to a narrow view of CSR [36] where business will only involve themselves in CSR related activities when there is a clear link to financial performance [37], . In this manner, CSR has been used as instrumental for the company to approach some important stakeholders.

Furthermore, in relation to the expectation toward CSR, by giving CSR as requested by some important stakeholders, the companies expect these stakeholders can assist them in securing the license permits, or calming down the local community protests. According to SKKMigas, one oil and gas company operating in Indonesia should secure around 270 various license permits from different government institutions in national, provincial and district level [38]. The complexity of license permits forces the company to utilize CSR to approach certain stakeholder who can able to assist them in securing the licenses. On the other hand, the local community members have a high expectation of CSR as they feel it is the only way for them to get something from the company. They don't care about the company cost and profit, as what they only know is the companies already taking their natural resources, and for that the companies have to pay the compensation to the local community.

From these three themes, the research concludes that the mandated law/ regulation on redistribution of wealth or resources from the company to the local community has been implemented in form of CSR projects. In the implementation and expectation themes, companies play an instrumental approach imposing their economic interest. As explained by [37] the instrumental approach of CSR lays on two basic criteria: the maximization of profits and the maximization of share value. All companies activities in this approach should be placed in economic nature, therefore [39] asserted that if the CSR activities of companies produce loss or decline in profits it indicates the activity is not considered an economic motive and even represent a flawed business decision [40]. Although the redistribution of wealth may decrease the shareholder profits and values by giving CSR projects to certain 
environments where corruption is pervasive and a company's strategy must contemplate dealings with potentially corrupt officials and integrate this with the management practices, particularly in CSR.

\section{REFERENCES}

Despite regulating the companies to carry out the business operations more responsible as often discussed in Western countries, the Indonesian CSR law mandates the redistribution of the company wealth or resources to the local community. Therefore, the essential part of the implementing regulation of CSR content is about the requirement of companies to allocate their budget to fund the CSR. In this manner, instead of creating the shareholder wealth by, for instance, making companies more efficient and competitive using, such as nonrenewable resources more efficiently or developing green technologies, CSR in Indonesia tends to decrease shareholder wealth or resources by allocating the spending cost to the community.

The budget allocation provided by the companies for CSR to the community has attracted some interested groups by exercising their power and influence to get CSR projects. Given the decentralization where the power and authority are distributed to the locals, the local stakeholders that have power and influence may exercise these to benefit from CSR projects. In this context, the companies will be forced to direct their CSR projects to this type of stakeholders, while the marginalized stakeholders are neglected. The company may do this 'voluntarily' if the spending gives them benefit in return such as the easiness to retain a license to operate, deflect criticism, or improve their brand images. The practice in delivering CSR projects to certain stakeholders can be categorized as a form of 'company compliance' because this practice follows the CSR law to allocate and distribute the CSR fund to the community. However, delivering CSR projects to certain specific stakeholders for these purposes may categorize as 'bribery practices'. As a result, this can reduce economic efficiency through poor allocation of resources, reduced wealth creation, lost government revenue, and increased income inequality.

Considering this situation, the law actually gives flexibility to the company to implement the CSR law as the mandatory is not on how the companies delivered the program, but rather on the allocation of budget for CSR. In this manner, the companies have the flexibility options and strategy in implementing CSR law, whether; to admit this 'bribery' practice in CSR as their adaptation strategy, or to implement good CSR in which eradicating corruption may become their main agenda. This may achieve by giving good practices in their businesses for not using CSR for 'bribery'. Moreover, the government should also take a further step in providing directions for the company in the implementation of CSR, such as to whom the company should do consultation and deliver the projects, and how to involve the local marginalized group. Eradicating corruption is one big problem in Indonesia and surely should be included in the CSR agenda. However, many scholars have not had much to say regarding strategies for avoiding or managing corruption, particularly in

\section{[1] Mumbunan, Sonny. (2013). Rente Industri Ekstraktif. Jakarta: Article} 33.

[2] Rosser, Andrew, \& Edwin, Donni. (2010). The politics of corporate social responsibility in Indonesia. The Pacific Review, 23(1), 1-22. doi: 10.1080/09512740903398314

[3] Achda, B. Tamam. (2006). The sociological context of corporate social responsibility development and implementation in Indonesia. Corporate social responsibility and environmental management, 13(5), 300-305. doi: $10.1002 /$ csr. 133

[4] Blowfield, Michael. (2005). Corporate social responsibility: reinventing the meaning of development? International Affairs, 81(3), 515-524.

[5] Dobers, Peter, \& Halme, Minna. (2009). Corporate social responsibility environmental management, 16(5), 237-249. doi: 10.1002/csr.212

[6] Jamali, Dima, \& Mirshak, Ramez. (2007). Corporate socia responsibility (CSR): Theory and practice in a developing country context. Journal of Business Ethics, 72(3), 243-262. doi: 10.1007/s10551-006-9168-4

[7] Alkire, Sabina. (2010). Human Development: Definitions, Critiques, and Related Concepts. UNDP HDRO Background Paper 2010/01.

[8] Prieto-Carrón, Marina, LUND-THOMSEN, PETER, Chan, Anita, Muro, ANA, \& Bhushan, Chandra. (2006). Critical perspectives on CSR and development: what we know, what we don't know, and what we need to know. International Affairs, 82(5), 977-987.

[9] Idemudia, Uwafiokun. (2007). Community perceptions and expectations: reinventing the wheels of corporate social responsibility practices in the Nigerian oil industry. Business and Society Review, 112(3), 369-405.

[10] Bishop, John. (1995). Adam Smith's invisible hand argument. Journal of Business Ethics, 14(3), 165-165.

[11] Blowfield, Michael, \& Frynas, Jedrzej George. (2005). Editorial Setting new agendas: critical perspectives on Corporate Social Responsibility in the developing world. International Affairs, 81(3), 499-513.

[12] Moon, Jeremy. (2004). Government as a driver of corporate socia responsibility. In D. Matten (Ed.), Research Paper Series (Vol. 20). Nottingham: ICCSR.

[13] Bachtiar, Palmira P. (2009). Regional Levy Collection as a Barrier to Investment Regional Regulations and their Impact on Business Climate. Jakarta: SMERU.

[14] Lister, Jane. (2011). Corporate Social Responsibility and the State: International Approaches to Forest Co-regulation: UBC Press.

[15] Gjølberg, Maria. (2011). Explaining regulatory preferences: CSR, soft law, or hard law? Insights from a survey of Nordic pioneers in CSR. Business and Politics, 13(2).

[16] Schulz, Wolfgang, \& Held, Thorsten. (2004). Regulated Self-Regulation as a Form of Modern Government: an analysis of case studies from media and telecommunications law: Indiana University Press.

[17] Porter, Michael E, \& Van der Linde, Claas. (1995). Green and competitive: ending the stalemate. Harvard business review, 73(5), 120 134.

[18] Neuman, W. Lawrence. (2007). Social Research Methods, 6/E: Pearson Education.

[19] Ministry of Energy and Mineral Resources. (2011). Indonesia energy statistics 2010: Center for data and information on energy and mineral resources.

[20] Robson, C. (2002). Real World Research: A Resource for Social Scientists and Practitioner-Researchers: Blackwell Publishers.

[21] Denzin, N.K. (2001). Interpretive Interactionism: SAGE Publications and developing countries. Corporate social responsibility and 
[33] Hamilton-Hart, Natasha. (2007). Government and private business: Rents, representation and collective action. Indonesia: Democracy and the promise of good governance, 93-113.

[22] Leedy, P.D., \& Ormrod, J.E. (2012). Practical Research: Planning and Design: Pearson.

[23] Holloway, Immy, \& Biley, Francis C. (2011). Being a qualitative researcher. Qualitative Health Research, 21(7), 968-975.

[24] Koestoer, Yanti T. (2007). Corporate Social Responsibility in Indonesia: Building internal corporate values to address challenges in CSR Implementation. Paper presented at the Seminar on Good Corporate and Social Governance in Promoting ASEAN's Regional Integration. ASEAN Secretariat. Jakarta.

[25] Yin, Robert. K, 2009, Studi Kasus; Desain dan Metode, Jakarta; Raja Grafindo Persada

[26] Greenwood, D.J., \& Levin, M. (2007). Introduction to action research: social research for social change: Sage Publications.

[27] Gummesson, E. (1999). Qualitative Methods in Management Research SAGE Publications.

[28] Arjaya, I Made, Bakri, Moch, \& Winarno, Bambang. (2014). Deviation Concept of CSR Regulation in Indonesia (Article 74 of Law 40 of 2007 on Limited Liability Company). Journal of Law, Policy and Globalization, 23, 1-7.

[29] Porter, Michael E, \& Kramer, Mark R. (2006). The link between competitive advantage and corporate social responsibility. Harvard Business Review, 12, 78493.

[30] Firman, Tommy. (2013). Territorial Splits (Pemekaran Daerah) in Decentralising Indonesia, 2000-2012: Local Development Drivers or Hindrance? Space and Polity, 17(2), 180-196.

[31] Agustina, Cut Dian, Ahmad, Ehtisham, Nugroho, Dhanie, \& Siagian, Herbert. (2012). Political economy of natural resources revenue sharing in Indonesia. Paper presented at the Paper submitted to a conference on Alternative Visions for Decentralization in Indonesia, Jakarta.

[32] Freeman, R Edward, \& Reed, David L. (1983). Stockholders and Stakeholders: A New Perspective on Corporate Governance. California management review, 25(3).
[34] Seidman, Irving. (2012). Interviewing as qualitative research: A guide for researchers in education and the social sciences: Teachers college press.

[35] Carroll, AB. (1991). The pyramid of corporate social responsibility: Toward the moral management of organizational stakeholders. Busines. Horizons, 34(4), 39-48.

[36] Berger, Ida E., Cunningham, Peggy, \& Drumwright, Minette E. (2007). Mainstreaming corporate social responsibility: Developing markets fo virtue. California management review, 49(4), 132-157.

[37] Carroll, Archie B., \& Shabana, Kareem M. (2010). The business case for corporate social responsibility: A review of concepts, research and practice. International journal of management reviews, 12(1), 85-105. doi: 10.1111/j.1468-2370.2009.00275.x

[38] Dhany, Rista Rama. (2013). Birokrasi Rumit, 1 Perusahaan Migas di RI Harus Penuhi 270 Izin. 27 March 2014, from http://finance.detik.com/read/2013/06/27/122140/2285765/1034/birokra si-rumit-1-perusahaan-migas-di-ri-harus-penuhi-270-izin

[39] Friedman, Milton. (2007). The social responsibility of business is to increase its profits. In W. C. Zimmerli, M. Holzinger \& K. Richter (Eds.), Corporate ethics and corporate governance (pp. 173-178): Springer Berlin Heidelberg.

[40] Schwartz, Mark S., \& Saiia, David. (2012). Should firms go "beyond profits"? Milton Friedman versus broad CSR.(Report). Business and Society Review, 117(1), 1(31) 